\title{
Sustainable Crop Production Protects the Quality of Soil and Plant Raw Materials
}

\author{
Małgorzata Szczepanek ${ }^{1, * \mathbb{D}}$, Anna Piotrowska-Długosz ${ }^{2}$ and Iwona Konopka ${ }^{3}$ \\ 1 Department of Agronomy, UTP University of Science and Technology in Bydgoszcz, S. Kaliskiego 7 Street, \\ 85-796 Bydgoszcz, Poland \\ 2 Laboratory of Soil Science and Biochemistry, Department of Biogeochemistry and Soil Science, UTP \\ University of Science and Technology in Bydgoszcz, Bernardyńska 6/8 Street, 85-029 Bydgoszcz, Poland; \\ apiotr@utp.edu.pl \\ 3 Chair of Plant Food Chemistry and Processing, University of Warmia and Mazury in Olsztyn, \\ 10-726 Olsztyn, Poland; Iwona.Konopka@uwm.edu.pl \\ * Correspondence: Malgorzata.Szczepanek@utp.edu.pl; Tel.: +48-602-502-165
}

check for

updates

Citation: Szczepanek, M.;

Piotrowska-Długosz, A.; Konopka, I. Sustainable Crop Production Protects the Quality of Soil and Plant Raw

Materials. Agronomy 2021, 11, 1178.

https://doi.org/10.3390/

agronomy11061178

Received: 11 May 2021

Accepted: 8 June 2021

Published: 10 June 2021

Publisher's Note: MDPI stays neutral with regard to jurisdictional claims in published maps and institutional affiliations.

Copyright: (c) 2021 by the authors. Licensee MDPI, Basel, Switzerland. This article is an open access article distributed under the terms and conditions of the Creative Commons Attribution (CC BY) license (https:// creativecommons.org/licenses/by/ $4.0 /)$.
Sustainable agriculture is defined in a broad context and includes environmental, economic, and social issues. Eckert and Breitschuh (1994) specified sustainable agriculture as "the management and utilization of the agricultural ecosystem in a way that maintains its biological diversity, productivity, regeneration capacity, vitality and ability to function, so that it can fulfill-today and in future-significant ecological, economic, and social functions at the local, national, and global level, and that does not harm other ecosystems" [1]. In turn, sustainable crop production refers to agricultural production in such a way that does not impose any harm to the environment, biodiversity, and quality of agricultural crops [2]. A sustainable crop production system is essential for ensuring healthy resources that are critical for the production of high-quality food and animal feed that are expected by consumers and the industry. The goal of sustainable crop production is not only to satisfy humanity's need for food and the industry's needs for raw materials, but to protect the environment and natural resources. Sustainable crop production practices develop efficient biological systems which do not need high levels of material inputs and include a variety of approaches that lead to an improvement in quality of food by using integrated pest management, protecting biodiversity, and maintaining good soil quality with a high organic matter content and microbial diversity. In order to avoid the potential harmful effects of high doses of pesticides, integrated pest management approaches that reduce their amount should be applied. Sustainable agriculture is associated with conservation practices that decrease the rate of soil and nutrient loss and reduce the amount of chemicals that are leached into the water table. The diversification of crops should also be considered. When possible, crops resistant to stressful environmental conditions should be selected. In annual cropping systems, crop rotation can be used to suppress weeds, pathogens, and insect pests. In addition, cover crops or intercrops can have a stabilizing effect on the agroecosystem by holding soil and nutrients in place, conserving soil moisture with mulches, and increasing the water infiltration rate and soil water holding capacity.

In sustainable crop production, it is extremely important to diversify species and varieties of crops, in particular the participation in the rotation of single or perennial legumes. One such plant is fodder galega (Galega orientalis Lam.) which is more tolerant to drought and frigid winter temperatures than other perennial legumes and could play an increased role as a protein crop and livestock feed in the future. Its outstanding persistence contributes to stable productivity and reduced incidences of reestablishment, an operation that typically involves tillage and exposing land to erosion. A 20-year-old stand of fodder galega remained productive and served as a valuable source of forage, and nutritive value was enhanced by fractionated harvest [3]. 
Modern agriculture tends to minimize the use of mineral fertilizers and chemical plant protection products, which are replaced by preparations of natural origin. This group of preparations includes biostimulants. They can make a significant contribution to environmental protection, but above all are closely linked to sustainable agricultural and horticultural production in order to obtain cheap, easily available and high-quality food. Agricultural biostimulants include a variety of substances and microorganisms that stimulate natural physiological processes of plants, promote nutrient uptake, resistance to stress, improve yield, and the quality of crops. The biostimulants significantly increase the yield component in maize (Zea mays L.) (the mass of one thousand seeds and the number of grains in the cob) [4]. In turn, the foliar application of biostimulants (e.g., seaweed extract and nitrophenols) in carrot (Daucus carota L.) counteract darkening of the roots. Moreover, algae extract increased the concentration of bioactive compounds (polyphenol, chlorogenic acid, flavonoids and anthocyanin pigments) in carrot roots [5]. Selection of biostimulants is important in relation to the accumulation capacity of total and true protein in potato (Solanum tuberosum L.) tubers [6].

The economical use of water resources is important in sustainable agricultural production. The main goal of research related to this issue is the estimation of water needs of agricultural and horticultural plants $[7,8]$. The research results may constitute the basis for designing resource-efficient irrigation programs necessary for agricultural and horticultural crops in light of the observed global climate change. On the other hand, common use of fertigation in agricultural practice can reduce the risk of environmental contamination. Drip irrigation, especially combined with drip fertigation, allows us to increase the productivity of crops [8].

Fertile, healthy soil is the main component of sustainable crop production. Only this type of soil will produce high-quality healthy crops that are less susceptible to disease and pests. While many crops have key pests that attack even the healthiest plants, proper soil, water, and nutrient management can help prevent some pest and disease problems that are caused by greater inputs of water, nutrients, pesticides, and/or energy for tillage that are required in order to maintain yields in high-input, resource-intensive production systems. This is why proper soil management will be of great importance for providing sustainable crop production and environmental sustainability, and for achieving food security and ensuring good human health in the future. In sustainable cultivation systems, soil must be protected and developed in order to ensure long-term productivity and stability. Protecting soil resources and improving their fertility and productivity can be achieved by application of exogenous organic matter, biofertilizers and/or conditioners; implementing appropriate soil conservation practices, such as using cover crops, compost, and/or manures; reducing tillage, and maintaining soil cover with plants and/or mulches. The changes occurring in the soil environment can be assessed by the special set of biological indicators of soil fertility and quality such as microbial abundance and functional diversity as well as enzymatic activity.

The use of waste exogenous organic matter, including spent mushroom substrate (SMS) and chicken manure (CM) as the basis of a soil-improving cropping system in sustainable agriculture has been considered [9]. Long-term (20 years) spent mushroom substrate (SMS) and chicken manure (CM) treatment increased soil fungal abundance and changed the fungal community structure at the genus and species level, but not completely at the phylum level. It was found that SMS and CM addition decreased the relative abundance of several potential crop pathogens. The application of various conditioners in agriculture is one of the management practices used to improve soil quality and plant growth and development. The tested conditioner was effective in improving the soil's water storage and soil $\mathrm{K}$ plant availability and helped improve the soil biological activity by increasing its enzymatic activity [10]. Although the amended conditioner is a promising approach for developing more sustainable agriculture, further research with different agricultural plants at different locations will be needed to confirm its effectiveness. 
The sixteen-year-long use of the reduced tillage method, legumes in crop rotation and the application of manure improved the soil quality for organic farming management, as compared with the conventional tillage method, cereals domination in crop rotation and the lack of manure in soil fertilization on conventional farming [11]. The statement was confirmed by significant improvement of different forms of soil organic carbon and nitrogen as well higher enzymatic activity by the organic farming system compared to the conventional system. In turn, after three years of field research with primary forms of wheat species (Triticum sphaerococcum Percival and Triticum persicum Vavilov) at different sowing densities, the soils of the conventional system were characterized by more favorable chemical properties $(\mathrm{pH}$, total organic carbon, macro- and micronutrients), glomalin, enzymatic activity and the number of insects than the organic system [12].

Fertilization is a key factor for sustaining productivity in agroecosystems responsible for improving soil environment. After 71 years since the establishment of a static fertilizer experiment, the chemical and biological properties of Luvisol have been changed significantly [13]. Generally, long-term fertilization, especially organic and mineral used together, improved soil properties. However, one-sided fertilization, especially mineral fertilization and fertilization that is imbalanced in terms of nutrients, caused a microbial imbalance in the soil and reduced the soil enzymatic activity. Especially, the long-term absence of manure adversely affected the chemical and biological properties of the soil, in particular reducing the activity of soil enzymes.

In conclusion, the current Special Issue includes several topics of research relative to the sustainable crop production by improving soil properties, highlighting the importance of biodiversity and environment preservation, while showing agronomic practices that are able to improve crop yield and quality.

Funding: This research received no external funding.

Institutional Review Board Statement: Not applicable.

Informed Consent Statement: Not applicable.

Conflicts of Interest: The authors declare no conflict of interest.

\section{References}

1. Lewandowski, I.; Härdtlein, M.; Kaltschmitt, M. Sustainable crop production definition and methodological approach for assessing and implementing sustainability. Crop Sci. 1999, 39, 184-193. [CrossRef]

2. Imadi, S.; Shazadi, K.; Gul, A.; Hakeem, K. Sustainable crop production system. In Plant, Soil and Microbes, Implications in Crop Science; Hakeem, K.R., Akhtar, M.S., Abdullah, S.N.A., Eds.; Springer: Cham, Switzerland, 2015; pp. 103-116. [CrossRef]

3. Ignaczak, S.; Andrzejewska, J.; Sadowska, K.; Albrecht, K.A. Fractional Harvest of Fodder Galega for Improved Herbage Nutritive Value. Agronomy 2021, 11, 480. [CrossRef]

4. Kapela, K.; Sikorska, A.; Niewęgłowski, M.; Krasnodębska, E.; Zarzecka, K.; Gugała, M. The Impact of Nitrogen Fertilization and the Use of Biostimulants on the Yield of Two Maize Varieties (Zea mays L.) Cultivated for Grain. Agronomy 2020, $10,1408$. [CrossRef]

5. Szczepanek, M.; Pobereżny, J.; Wszelaczyńska, E.; Gościnna, K. Effect of Biostimulants and Storage on Discoloration Potential of Carrot. Agronomy 2020, 10, 1894. [CrossRef]

6. Zarzecka, K.; Gugała, M.; Mystkowska, I.; Sikorska, A. Total and True Protein Content in Potato Tubers Depending on Herbicides and Biostimulants. Agronomy 2020, 10, 1106. [CrossRef]

7. Jagosz, B.; Rolbiecki, S.; Rolbiecki, R.; Łangowski, A.; Sadan, H.A.; Ptach, W.; Stachowski, P.; Kasperska-Wołowicz, W.; Pal-Fam, F.; Liberacki, D. The Water Needs of Grapevines in Central Poland. Agronomy 2021, 11, 416. [CrossRef]

8. Rolbiecki, R.; Rolbiecki, S.; Figas, A.; Jagosz, B.; Stachowski, P.; Sadan, H.A.; Prus, P.; Pal-Fam, F. Requirements and Effects of Surface Drip Irrigation of Mid-Early Potato Cultivar Courage on a Very Light Soil in Central Poland. Agronomy 2021, 11, 33. [CrossRef]

9. Frac, M.; Pertile, G.; Panek, J.; Gryta, A.; Oszust, K.; Lipiec, J.; Usowicz, B. Mycobiome Composition and Diversity under the Long-Term Application of Spent Mushroom Substrate and Chicken Manure. Agronomy 2021, 11, 410. [CrossRef]

10. Długosz, J.; Piotrowska-Długosz, A.; Kotwica, K.; Przybyszewska, E. Application of Multi-Component Conditioner with Clinoptilolite and Ascophyllum nodosum Extract for Improving Soil Properties and Zea mays L. Growth and Yield. Agronomy 2020, 10, 2005. [CrossRef] 
11. Kobierski, M.; Lemanowicz, J.; Wojewódzki, P.; Kondratowicz-Maciejewska, K. The Effect of Organic and Conventional Farming Systems with Different Tillage on Soil Properties and Enzymatic Activity. Agronomy 2020, 10, 1809. [CrossRef]

12. Lemanowicz, J.; Bartkowiak, A.; Lamparski, R.; Wojewódzki, P.; Pobereżny, J.; Wszelaczyńska, E.; Szczepanek, M. Physicochemical and Enzymatic Soil Properties Influenced by Cropping of Primary Wheat under Organic and Conventional Farming Systems. Agronomy 2020, 10, 1652. [CrossRef]

13. Jaskulska, I.; Lemanowicz, J.; Breza-Boruta, B.; Siwik-Ziomek, A.; Radziemska, M.; Dariusz, J.; Białek, M. Chemical and Biological Properties of Sandy Loam Soil in Response to Long-Term Organic-Mineral Fertilisation in a Warm-Summer Humid Continental Climate. Agronomy 2020, 10, 1610. [CrossRef] 